\title{
Effects of Graded Levels of Joy Perfume Tree (Pentadiplandra brazzeana) Powder in Drinking Water on Growth Performance, Gut Microbiota and Haemato-Biochemical Parameters of Broiler Chickens
}

\author{
Tsafack Boris Necdem" ${ }^{*}$ Kana Jean Raphaël1, Yemdjie Mane Divine², Ebile Dayan Agwah1, \\ Ngouana Tadjong Ruben', Donfack Mikael'1, Tchouan Deffo Gilchrist ${ }^{1}$, \\ Kengni Noubissie Josiane ${ }^{1}$, Teguia Alexis ${ }^{1}$

\begin{abstract}
${ }^{1}$ Animal Production and Nutrition Research Unit, Department of Animal sciences, Faculty of Agronomy and Agricultural Sciences, University of Dschang, Dschang, Cameroon

${ }^{2}$ Laboratory of Aquatic Ressources, Department of Aquaculture, Institute of Fisheries and Aquatic Sciences, University of Douala, Douala, Cameroon

Email: ^Borisnecdem@yahoo.fr
\end{abstract}

How to cite this paper: Necdem, T.B., Raphaël, K.J., Divine, Y.M., Agwah, E.D., Ruben, N.T., Mikael, D., Gilchrist, T.D., Josiane, K.N. and Alexis, T. (2020) Effects of Graded Levels of Joy Perfume Tree (Pentadiplandra brazzeana) Powder in Drinking Water on Growth Performance, Gut Microbiota and Haemato-Biochemical Parameters of Broiler Chickens. Open Journal of Animal Sciences, 10, 514-527. https://doi.org/10.4236/ojas.2020.103032

Received: April 28, 2020

Accepted: July 7, 2020

Published: July 10, 2020

Copyright (๑) 2020 by author(s) and Scientific Research Publishing Inc. This work is licensed under the Creative Commons Attribution International License (CC BY 4.0).

http://creativecommons.org/licenses/by/4.0/ (c) (i) Open Access

\begin{abstract}
The restriction of antibiotic growth promoters in livestock nutrition has led to a growing interest in plant feed additives. This study was designed to assess the production performance of broiler chickens fed on graded levels of Pentadiplandra brazzeana powder in drinking water. A total of 448 day-old Cobb 500 broiler chicks were randomly assigned to seven treatment groups with 4 replicates of 16 birds each ( 08 males and 08 females). Pentadiplandra brazzeana root was grounded and incorporated at 1,2, 3, 4 and $5 \mathrm{~g} / \mathrm{L}$ of drinking water. Control rations consisted of diet without any supplement (T0) and antibiotic (1 $\mathrm{g} / \mathrm{kg}$ ) medicated diet ( $\mathrm{T} 0+$ ). Throughout the experimental period (49 days) feed intake was not significantly ( $p>0.05$ ) affected by graded levels of Pentadiplandra brazzeana except for $5 \mathrm{~g} / \mathrm{L}$ of water that significantly $(\mathrm{p}<0.05)$ decreased feed intake. Weight gain was significantly higher $(\mathrm{p}<0.05)$ with 1,2 and 3 $\mathrm{g} / \mathrm{L}$, while feed conversion ratio was significantly lower $(\mathrm{p}<0.05)$ with the same treatments compared to the control group (T0). Chickens fed on $1 \mathrm{~g}$ Pentadiplandra brazzeana/L recorded a higher $(\mathrm{p}<0.05)$ carcass yield compared to the control ration (T0). Haematological parameters were not significantly $(p>0.05)$ affected irrespective of the level of incorporation of the test spice in drinking water. Serum content in urea was significantly lower $(\mathrm{p}<0.05)$ with $3 \mathrm{~g}$ Pentadiplandra brazzeana/L compared to all other
\end{abstract}


treatments. ASAT, ALAT, creatinine, total cholesterol, triglycerides, HDL and LDL-cholesterol were not significantly affected by the inclusion of Pentadiplandra brazzeana powder in drinking water. Feeding chickens with up to $4 \mathrm{~g}$ of Pentadiplandra brazzeana significantly increased $(\mathrm{p}<0.05)$ lactic acid bacteria count. E. coli and salmonella counts significantly $(\mathrm{p}<0.05)$ decreased with the spice in water as compared to the control diet. In conclusion, the administration of up to $3 \mathrm{~g}$ of Pentadiplandra brazzeana powder through drinking water can be used as alternative to antibiotics to improve growth performance of broiler chickens.

\section{Keywords}

Broilers, Growth Performance, Gut Microbiota, Haemato-Biochemical Parameters, Pentadiplandra brazzeana

\section{Introduction}

This last decade, medicinal herbs, aromatic plant and spices have gain more interest in animal nutrition, particularly in poultry production for the improvement of health and animal wellbeing. This growing interest in herbal feed additives in livestock production known as phytogenic feed additives is due to the development of microbial resistance to antibiotic feed additives. Phytobiotic or phytogenic is known as any compound of plant origin which is incorporated in animal feed to improve growth performance through its anti-oxidative, antimicrobial action, improved palatability and the maintenance of gut equilibrium [1].

The primary mode of action of growth promoting feed additives can be attributed mainly to the stabilization of feed hygiene and also from the beneficial effect on the gastrointestinal microbiota through controlling pathogens [2]. They also stimulate digestive enzyme and gastric secretion [3]. All these beneficial properties of phytobiotic are due to the presence of actives substances such as phenol, tannins, alkaloids and terpenoïds [4]. The main beneficial effects of these products in animal industry belong to their ability to activate feed intake and digestive secretion, anti-inflammatory activity, antimicrobial and antioxydant properties. Previous study revealed that Zingiber officinale and Allium sativum [5], Tetrapleura tetraptera, Afrostyrax lepidophyllus and Dichrostachys glomerata improve growth performance of broiler chickens [6] [7] [8].

Pentadipladra brazzeana is a shrub or climbing plant found at the edge of rivers, savannah and in secondary forests in Nigeria, Central Africa, Democratic Republic of Congo and Angola [9]. Its roots are commonly harvested by the local population and used as tonic, aphrodisiac, antiblennorragic, antalgic and antisyphilitic [10] [11]. Phytochemical test of this root revealed the presence of alkaloids, isothiocyanates, flavonoids, tannins, phenols and triterpernes [12] possessing several biological activities. In vitro studies on this plant revealed antimicrobial activity against Escherichia coli, Shigella flexneri, Salmonella typhi and antifungal activity against Candida albicans [13]. Other studies revealed anti- 
oxidant [14] and cytotoxic [15] properties of this plant. Based on these properties and actives metabolites found in this spice we believed it could balance gut microflora, ensure good health and welfare, which can positively affect growth performances of animals. The main objective of this study was to assess the effect of graded level of Pentadiplandra brazzeana root powder as feed additive on growth performance, gut microbiota, haematological and biochemical parameters of broiler chickens.

\section{Materials and Methods}

The study was carried out at the Teaching and Research Farm of the Faculty of Agronomy and Agricultural Sciences, University of Dschang, Cameroon, from July to August 2019.

Trial has been performed in agreement with the guidelines of the ethical standards from the 1964 Helsinki declaration and latterly amendment.

\subsection{Feed Additive}

Dried sample of Pentadiplandra brazzeana roots was bought at the local market in Ballessing (Menoua Division, Cameroon), ground into powder in a harmed mill, sieved and incorporated in drinking water. Sample of the grounded spices was kept in polyethylene plastics at $4^{\circ} \mathrm{C}$ for phytochemical analysis. Antibiotic $\left(\right.$ Doxycyclin ${ }^{\circledR}$ ) used in the positive control diet was bought from a local veterinary pharmacy.

\subsection{Animal and Experimental Diets}

A total of 448 one day old Cobb 500 broiler chicks were assigned to seven treatment groups in a completely randomized design with 64 birds per treatment. Each group was sub divided into 4 replicates of 16 birds each (08 males and 08 females).

A mash basal diet (T0) was formulated to meet the nutritional requirements of the animal (Table 1). From this basal diet, the positive control diet (T0+) was obtained by incorporating $1 \mathrm{~g}$ of antibiotic/kg of feed. The five other treatments consisted of incorporating 1, 2, 3, 4 and $5 \mathrm{~g}$ of Pentadiplandra brazzeana powder per liter of drinking water 24 hours before being given to the animals. Feed and water were offered ad libitum. Throughout the experiment, birds were given vaccines in drinking water against Newcastel disease and Infectious Bronchitis on the $7^{\text {th }}$ day with a booster dose on the 18th day of age, and against Gumboro disease on the $10^{\text {th }}$ day of age. Coccidiosis prevention was done using Vetacox ${ }^{\circledR}$ for 3 consecutive days per week from the $2^{\text {nd }}$ to the $6^{\text {th }}$ week of age. Birds were administrated commercial antistress in drinking water during the first 3 days upon arrival and after each weighing session. Pen body weights were recorded at the beginning of the experiment and on a weekly basis thereafter. Pen Data on feed intake (FI) and body weight gain (BWG) were collected and use to calculate feed conversion ratio (FCR) using the following formula FCR $=$ FI/BWG. Data on water intake were recorded on daily basis pen wise. 
Table 1. Composition of basal diet.

\begin{tabular}{ccc}
\hline Ingredients \% & Starter & Finisher \\
\hline Maize & 60 & 70 \\
Wheat bran & 3 & 0 \\
Soybean meal & 21 & 14 \\
Coton seed meal & 5 & 5 \\
Fish meal & 5 & 5 \\
Oeister shell & 1 & 1 \\
CMAV5\%* & 5 & 5 \\
Total & 100 & 100 \\
\hline Calculated analysis & 3010.50 \\
Crude protein (\%) & 2910.05 & 19.29 \\
Crude fibre (\%) & 22.48 & 4.94 \\
Energy/protein & 4.96 & 156.06 \\
Calcium (\%) & 129.45 & 1.15 \\
Phosphorous (\%) & 1.17 & 0.44 \\
Lysine (\%) & 0.49 & 1.15 \\
Methionine (\%) & 1.37 & 0.44 \\
\hline Metabolizable energy (Kcal/kg) & 0.48 & \\
\hline & 248 & \\
\hline
\end{tabular}

*CMAV 5\%: crude proteins $400 \mathrm{mg}$, Lysin $33 \mathrm{mg}$, Methionin $24 \mathrm{mg}$, Calcium $80 \mathrm{mg}$, Phosphorous $20.5 \mathrm{mg}$, metabolizable energy $2078 \mathrm{kcal} / \mathrm{kg}$, Vitamins: Retinol 10,000,000 IU, Cholecalciferol 3,000,000 UI, Tocopherol 2500 IU, Phylloquinon 4000 mg, Thiamin 5000 mg, Riboflavin 500 mg, Pyridoxin 2500 mg, Cyanocobalamin $5 \mathrm{mg}$, Folic acid 10,000 mg and Niacin $2000 \mathrm{mg}$.

\subsection{Growth Performance, Carcass Traits, Haematological and Serum Biochemical}

Feed intake, weight gain and feed conversion ratio were evaluated on a weekly basis in both starter and finisher phases of the study. At 49 days of age, ten chicks ( 5 male and 5 female) of each group were randomized appropriated, fasted for 24 hours before slaughter and individually weighted. After scalding, feather picking and evisceration carcass, organs (liver, gizzard, heart, pancreas, abdominal fat, cecum and intestine). From each slaughtered bird, blood was collected in 2 test tubes, one of which containing anticoagulant (EDTA). Blood with anticoagulant was used for haematological analysis using a fully automatic blood cell counter (model PCE-210N Hong kong, china). Haematological parameters studed that has been determinate included White blood cell (WBC), Red blood cell (RBC), Haemoglobin (Hgb), Mean cell haemoglobin concentration (MCHC), Mean cell volume (MCV), Mean cell haemoglobin (MCH) and Packed cell volume (PCV). After centrifugation at $4000 \mathrm{rpm}$ for $20 \mathrm{~min}$ of blood free from anticoagulant, serum was collected and preserved at $-20^{\circ} \mathrm{C}$ for the total protein, albumin, globulin, aspartate aminotransferase (ASAT), alanine aminotransferase (ALAT), total cholesterol, high density lipoproteins (HDL), low density lipo- 
protein (LDL), triglycerides, urea and creatinine quantification, using the colorimetric method as prescribed by the non-specific chickens commercial kits (Spinreact ${ }^{\circledR}$ kits).

\subsection{Microbial Count}

At the end of the study period at 49 days, freshly bird feces were collected through cloacal swab. The identification and quantification of bacteria were assessed on appropriate specific culture media (MRS Agar for lactic acid bacteria, Mac conkey Agar for E. coli, SS Agar for Salmonella). Samples were incubated at $37^{\circ} \mathrm{C}$ for 24 hours.

\subsection{Statistical Analysis}

Data collected on growth, carcass, haemotological, biochemical and microbial parameters were submitted to one-way analysis of variance test by the general linear model procedure of Statistical Package for Social Science (SPSS 20.0) software. The differences were tested using Duncan's test and probability values less than 0.05 was considered as significant [16].

\section{Results}

Table 2 summarizes the overall growth performance of broilers chickens supplemented with graded levels of Pentadiplandra brazzeana root powder through drinking water. Whatever the period of the study, there is a linear decrease $(\mathrm{p}<$ 0.05 ) in water intake with the increasing levels of Pentadiplandra brazzeana powder. During the brooding phase, the results indicated no significant effect $(\mathrm{p}>0.05)$ among the treatment groups for feed intake during. During the growing phase and throughout the experimental period, birds fed on $5 \mathrm{~g} P$. brazzeana powder recorded the lowest $(\mathrm{p}<0.05)$ feed intake of all the treatments.

At the brooding phase, birds fed on 2 and $3 \mathrm{~g} P$. brazzeana powder through water recorded the highest $(\mathrm{p}<0.05)$ live body weight and weight gain of all the treatments, while birds fed on $5 \mathrm{~g}$ of this phytobiotic recorded the lowest $(\mathrm{p}<$ $0.05)$ live body weight and weight gain. Throughout the trial, birds fed on antibiotic, 1,2 and $3 \mathrm{~g} P$. brazzeana powder recorded the highest $(\mathrm{p}<0.05)$ live body weight and weight gain compared to birds fed on the negative control diet, 4 and $5 \mathrm{~g} P$. brazzeana powder. Live body weight and weight gain decreased linearly with increasing levels of $P$. brazzeana in drinking water.

During the growing phase and throughout the experimental period, birds fed on antibiotic and $P$. brazzeana powder at 1,2 and $3 \mathrm{~g} / \mathrm{L}$ recorded the lowest ( $\mathrm{p}>$ 0.05 ) feed conversion ratio compared to bird fed on control diet without additive.

Carcass characteristics and relative weight of organs expressed in proportion of body weight of broilers fed on graded levels of $P$. brazzeana powder are presented in Table 3. The average value of carcass yield of broilers fed on diet supplemented with antibiotic and with $1 \mathrm{~g} P$. brazzeana/L was significantly higher 
Table 2. Growth performance of broiler chickens supplemented on graded levels of Pentadiplandra brazzeana.

\begin{tabular}{|c|c|c|c|c|c|c|c|c|}
\hline \multirow{2}{*}{$\begin{array}{l}\text { Study } \\
\text { phase } \\
\text { (days) }\end{array}$} & \multicolumn{8}{|c|}{ Treatments } \\
\hline & T0 & T0+ & $1 \mathrm{~g} / \mathrm{L}$ & $2 \mathrm{~g} / \mathrm{L}$ & $3 \mathrm{~g} / \mathrm{L}$ & $4 \mathrm{~g} / \mathrm{L}$ & $5 \mathrm{~g} / \mathrm{L}$ & P-value \\
\hline \multicolumn{9}{|c|}{ Water intake (ml) } \\
\hline $01-21$ & $2109.17 \pm 53.64^{\mathrm{a}}$ & $1990.17 \pm 103.41^{\mathrm{ab}}$ & b $2106.23 \pm 53.35^{\mathrm{a}}$ & $1968.39 \pm 130.35^{\mathrm{ab}}$ & $1967.25 \pm 104.03^{\mathrm{ab}}$ & $1902.06 \pm 124.24^{\mathrm{b}}$ & $1870.75 \pm 136.27^{\mathrm{b}}$ & 0.02 \\
\hline $22-49$ & $8528.54 \pm 114.04^{\mathrm{a}}$ & $8364.43 \pm 125.20^{\mathrm{ab}}$ & $\mathrm{b} 8426.73 \pm 174.48^{\mathrm{ab}}$ & $8193.20 \pm 179.52^{\mathrm{b}}$ & $8140.75 \pm 271.73^{b}$ & $8118.46 \pm 266.42^{\mathrm{b}}$ & $7814.50 \pm 151.46^{c}$ & 0.01 \\
\hline $01-49$ & $10,637.71 \pm 274.49^{\mathrm{a}}$ & $\mathrm{a} 10,480.00 \pm 369.43^{\mathrm{ab}}$ & $10,532.96 \pm 230.64^{\mathrm{ab}}$ & $10,161.59 \pm 275.73^{b c}$ & $=10,149.00 \pm 261.84^{\mathrm{bc}}$ & $10,020.53 \pm 346.61^{\mathrm{cd}}$ & $9685.25 \pm 221.18^{d}$ & 0.01 \\
\hline \multicolumn{9}{|c|}{ Feed intake (g) } \\
\hline $01-21$ & $1009.28 \pm 31.08$ & $998.58 \pm 61.55$ & $1058.47 \pm 44.74$ & $1057.79 \pm 23.97$ & $1052.38 \pm 31.89$ & $1028.41 \pm 75.79$ & $991.63 \pm 81.41$ & 0.43 \\
\hline $22-49$ & $4262.92 \pm 61.04^{\mathrm{ab}}$ & $4342.51 \pm 38.91^{a}$ & $4249.69 \pm 49.39^{\mathrm{b}}$ & $4238.49 \pm 46.49^{b}$ & $4197.78 \pm 71.66^{\mathrm{b}}$ & $4188.46 \pm 60.35^{\mathrm{b}}$ & $4039.06 \pm 42.73^{c}$ & 0.01 \\
\hline $01-49$ & $5272.20 \pm 85.42^{\mathrm{a}}$ & $5341.10 \pm 65.25^{\mathrm{a}}$ & $5308.17 \pm 89.86^{\mathrm{a}}$ & $5296.28 \pm 57.62^{\mathrm{a}}$ & $5250.17 \pm 78.27^{\mathrm{a}}$ & $5216.87 \pm 98.47^{\mathrm{a}}$ & $5030.69 \pm 105.98^{\mathrm{b}}$ & 0.01 \\
\hline \multicolumn{9}{|c|}{ Live weight (g) } \\
\hline $01-21$ & $684.52 \pm 26.56^{\mathrm{b}}$ & $677.50 \pm 9.20^{\mathrm{b}}$ & $685.31 \pm 6.84^{\mathrm{b}}$ & $710.63 \pm 21.66^{\mathrm{a}}$ & $713.45 \pm 14.88^{\mathrm{a}}$ & $679.38 \pm 15.24^{\mathrm{b}}$ & $651.61 \pm 8.27^{\mathrm{c}}$ & 0.01 \\
\hline $22-49$ & $2480.31 \pm 90.00^{\mathrm{b}}$ & $2657.86 \pm 43.66^{a}$ & $2648.26 \pm 96.51^{a}$ & $2641.10 \pm 52.37^{\mathrm{a}}$ & $2629.94 \pm 77.10^{\mathrm{a}}$ & $2520.16 \pm 40.87^{b}$ & $2473.42 \pm 34.82^{\mathrm{b}}$ & 0.01 \\
\hline \multicolumn{9}{|c|}{ Weight gain $(\mathrm{g})$} \\
\hline $01-21$ & $644.52 \pm 26.56^{\mathrm{b}}$ & $637.50 \pm 9.20^{\mathrm{b}}$ & $645.31 \pm 6.84^{\mathrm{b}}$ & $670.63 \pm 21.62^{\mathrm{a}}$ & $673.45 \pm 14.86^{\mathrm{a}}$ & $639.38 \pm 15.24^{\mathrm{b}}$ & $611.61 \pm 8.27^{c}$ & 0.01 \\
\hline $22-49$ & $1795.79 \pm 91.22^{c}$ & $1980.37 \pm 50.24^{\mathrm{a}}$ & $1962.95 \pm 100.16^{\mathrm{a}}$ & $1943.59 \pm 40.65^{\mathrm{ab}}$ & $1934.75 \pm 86.09^{\mathrm{ab}}$ & $1840.78 \pm 50.66^{b c}$ & $1806.49 \pm 49.15^{c}$ & 0.01 \\
\hline $01-49$ & $2440.31 \pm 86.00^{\mathrm{b}}$ & $2617.88 \pm 43.66^{\mathrm{a}}$ & $2608.26 \pm 96.51^{a}$ & $2601.22 \pm 40.22^{\mathrm{a}}$ & $2589.28 \pm 96.22^{\mathrm{a}}$ & $2480.16 \pm 40.87^{\mathrm{b}}$ & $2433.10 \pm 46.12^{\mathrm{b}}$ & 0.01 \\
\hline \multicolumn{9}{|c|}{ Feed conversion ratio } \\
\hline $01-21$ & $1.57 \pm 0.10$ & $1.57 \pm 0.09$ & $1.64 \pm 0.05$ & $1.57 \pm 0.04$ & $1.57 \pm 0.09$ & $1.60 \pm 0.10$ & $1.62 \pm 0.12$ & 0.90 \\
\hline $22-49$ & $2.38 \pm 0.12^{\mathrm{a}}$ & $2.17 \pm 0.03^{\mathrm{b}}$ & $2.17 \pm 0.11^{\mathrm{b}}$ & $2.20 \pm 0.14^{\mathrm{b}}$ & $2.17 \pm 0.06^{\mathrm{b}}$ & $2.28 \pm 0.05^{\mathrm{ab}}$ & $2.24 \pm 0.07^{\mathrm{ab}}$ & 0.04 \\
\hline $01-49$ & $2.16 \pm 0.06^{\mathrm{a}}$ & $2.04 \pm 0.04^{\mathrm{b}}$ & $2.04 \pm 0.09^{\mathrm{b}}$ & $2.04 \pm 0.11^{\mathrm{b}}$ & $2.03 \pm 0.4^{\mathrm{b}}$ & $2.10 \pm 0.02^{\mathrm{ab}}$ & $2.08 \pm 0.08^{\mathrm{ab}}$ & 0.04 \\
\hline
\end{tabular}

a,b,c: Means on the same row with different superscripts are significantly different $(\mathrm{P}<0.05) . \mathrm{p}=$ probability. $\mathrm{T} 0=$ negative control diet; $\mathrm{T} 0+=\mathrm{T} 0+0.1 \%$ of Doxycycline.

Table 3. Effects of graded levels of Pentadplandra brazzeana on carcass yield and relative organs weight of broiler chickens.

\begin{tabular}{ccccccccc}
\hline \multirow{2}{*}{ Parameters (\% BW) $)$} & \multicolumn{7}{c}{ Treatments } \\
\cline { 2 - 9 } & T0 & T0 + & $\mathbf{1} \mathbf{g} / \mathbf{L}$ & $\mathbf{2} \mathbf{g} / \mathbf{L}$ & $\mathbf{3} \mathbf{g} / \mathbf{L}$ & $\mathbf{4} \mathbf{g} / \mathbf{L}$ & $\mathbf{5} \mathbf{g} / \mathbf{L}$ & P-value \\
\hline Carcass yield & $72.34 \pm 1.88^{\mathrm{bc}}$ & $74.26 \pm 1.54^{\mathrm{a}}$ & $74.20 \pm 1.26^{\mathrm{a}}$ & $73.47 \pm 1.30^{\mathrm{ab}}$ & $73.40 \pm 1.42^{\mathrm{ab}}$ & $71.81 \pm 1.37^{\mathrm{c}}$ & $71.81 \pm 1.48^{\mathrm{c}}$ & 0.01 \\
Head & $2.01 \pm 0.17$ & $1.97 \pm 0.26$ & $2.01 \pm 0.22$ & $2.16 \pm 0.30$ & $2.11 \pm 0.48$ & $2.15 \pm 0.27$ & $1.99 \pm 0.29$ & 0.63 \\
Legs & $3.77 \pm 0.51$ & $3.37 \pm 0.49$ & $3.55 \pm 0.34$ & $3.57 \pm 0.41$ & $3.41 \pm 0.34$ & $3.43 \pm 0.33$ & $3.53 \pm 0.54$ & 0.44 \\
Liver & $1.84 \pm 0.18$ & $1.80 \pm 0.31$ & $1.72 \pm 0.32$ & $1.73 \pm 0.13$ & $1.70 \pm 0.51$ & $1.76 \pm 0.20$ & $1.70 \pm 0.26$ & 0.93 \\
Gizzard & $1.46 \pm 0.20$ & $1.34 \pm 0.10$ & $1.41 \pm 1.22$ & $1.39 \pm 0.12$ & $1.37 \pm 0.19$ & $1.43 \pm 0.17$ & $1.33 \pm 0.16$ & 0.49 \\
Heart & $0.57 \pm 0.08^{\mathrm{a}}$ & $0.44 \pm 0.06^{\mathrm{b}}$ & $0.49 \pm 0.06^{\mathrm{b}}$ & $0.49 \pm 0.08^{\mathrm{b}}$ & $0.48 \pm 0.06^{\mathrm{b}}$ & $0.48 \pm 0.07^{\mathrm{b}}$ & $0.46 \pm 0.07^{\mathrm{b}}$ & 0.01 \\
Pancréas & $0.21 \pm 0.07$ & $0.17 \pm 0.04$ & $0.20 \pm 0.05$ & $0.20 \pm 0.06$ & $0.18 \pm 0.04$ & $0.21 \pm 0.07$ & $0.24 \pm 0.12$ & 0.51 \\
Abdominal fat & $1.62 \pm 0.77$ & $1.66 \pm 0.82$ & $1.65 \pm 0.64$ & $1.82 \pm 0.86$ & $1.35 \pm 0.63$ & $1.48 \pm 0.55$ & $1.71 \pm 0.87$ & 0.86 \\
\hline
\end{tabular}

a,b,c: Means on the same row with different superscripts are significantly different $(\mathrm{P}<0.05) . \mathrm{p}=$ probability. $\mathrm{T} 0=$ negative control diet; $\mathrm{T} 0+=\mathrm{T} 0+0.1 \%$ of Doxycycline.

$(\mathrm{p}<0.05)$ compared to birds fed on negative control diet and 4 and $5 \mathrm{~g}$ P. brazzeana/L. There was no marked ( $\mathrm{p}>0.05$ ) effects on the relative weight of the liv- 
er, gizzard, pancreas, legs and abdominal fat. The relative weight of heart decreased significantly $(\mathrm{p}<0.05$ ) in birds fed on different level of $P$. brazzeana powder compared to birds fed on negative control diet.

Table 4 indicates the effects of graded levels of $P$. brazzeana powder on haematological parameters of broiler chickens at 49 days of age. Feeding broilers with Pentadiplandra brazzeana powder had no significant effects on blood haematological parameters irrespective of the level of incorporation in drinking water.

Table 5 indicates that feeding broiler chickens with $3 \mathrm{~g}$ Pentadiplandra brazzeana/L significantly $(\mathrm{p}<0.05)$ decrease urea serum content compare to other treatments. Birds fed with antibiotic medicated diet recorded the highest $(\mathrm{p}<$ 0.05) ASAT serum content of all the treatment. Inclusion of graded level of $P$. brazzeana powder in broilers drinking water induced a non-significant decreased in LDL-cholesterol serum level compare to negative control diet.

The results on the intestinal microbial count are summarized in Table 6. A significant increased $(\mathrm{p}<0.05)$ was recorded on lactic acid bacteria count with

Table 4. Effects of graded levels of Pentadiplandra brazzeana powder in drinking water on haematological parameters of chickens.

\begin{tabular}{|c|c|c|c|c|c|c|c|c|}
\hline \multirow{2}{*}{ Parameters } & \multicolumn{7}{|c|}{ Treatments } & \multirow[b]{2}{*}{$\mathrm{P}$-value } \\
\hline & T0 & T0+ & $1 \mathrm{~g} / \mathrm{L}$ & $2 \mathrm{~g} / \mathrm{L}$ & $3 \mathrm{~g} / \mathrm{L}$ & $4 \mathrm{~g} / \mathrm{L}$ & $5 \mathrm{~g} / \mathrm{L}$ & \\
\hline $\mathrm{WBC}\left(10^{3} / \mu \mathrm{l}\right)$ & $89.84 \pm 7.96$ & $83.67 \pm 5.66$ & $84.08 \pm 7.48$ & $88.90 \pm 5.92$ & $88.42 \pm 6.76$ & $93.10 \pm 4.24$ & $89.33 \pm 4.94$ & 0.27 \\
\hline $\mathrm{RBC}(106 / \mu \mathrm{l})$ & $2.79 \pm 0.28$ & $2.79 \pm 0.19$ & $2.78 \pm 0.16$ & $2.87 \pm 0.11$ & $2.85 \pm 0.19$ & $2.86 \pm 0.13$ & $2.82 \pm 0.16$ & 0.86 \\
\hline $\mathrm{Hgb}(\mathrm{g} / \mathrm{dl})$ & $13.84 \pm 0.30$ & $13.70 \pm 0.48$ & $13.83 \pm 0.26$ & $14.13 \pm 0.57$ & $14.14 \pm 0.43$ & $14.14 \pm 0.18$ & $13.95 \pm 0.43$ & 0.88 \\
\hline PCV (\%) & $41.62 \pm 1.80$ & $41.87 \pm 1.40$ & $41.81 \pm 0.99$ & $43.70 \pm 1.70$ & $43.06 \pm 0.96$ & $43.14 \pm 0.64$ & $42.37 \pm 0.78$ & 0.16 \\
\hline $\operatorname{MCV}(\mathrm{fL})$ & $150.36 \pm 2.95$ & $149.85 \pm 2.26$ & $150.68 \pm 3.94$ & $150.35 \pm 2.18$ & $153.82 \pm 5.73$ & $152.74 \pm 5.24$ & $151.82 \pm 3.89$ & 0.76 \\
\hline $\mathrm{MCH}(\mathrm{pg})$ & $48.18 \pm 2.85$ & $46.45 \pm 1.61$ & $48.75 \pm 2.08$ & $47.30 \pm 2.69$ & $48.46 \pm 1.83$ & $47.88 \pm 1.52$ & $48.07 \pm 1.52$ & 0.67 \\
\hline $\operatorname{PLT}\left(10^{3} / \mu \mathrm{l}\right)$ & $45.75 \pm 4.57$ & $44.25 \pm 4.50$ & $48.00 \pm 4.64$ & $47.33 \pm 3.37$ & $44.40 \pm 4.56$ & $46.40 \pm 3.28$ & $48.75 \pm 3.68$ & 0.57 \\
\hline
\end{tabular}

Table 5. Effects of graded levels of Pentadiplandra brazzeana powder in drinking water on biochemical parameters of chickens.

\begin{tabular}{|c|c|c|c|c|c|c|c|c|c|}
\hline \multirow{2}{*}{ Parameters } & \multicolumn{8}{|c|}{ Treatments } & \multirow[b]{2}{*}{ P-value } \\
\hline & T0 & T0+ & $1 \mathrm{~g} / \mathrm{L}$ & $2 \mathrm{~g} / \mathrm{L}$ & $3 \mathrm{~g} / \mathrm{L}$ & $4 \mathrm{~g} / \mathrm{L}$ & $5 \mathrm{~g} / \mathrm{L}$ & SEM & \\
\hline ASAT (U/I) & $140.98^{\mathrm{b}}$ & $212.95^{\mathrm{a}}$ & $178.60^{\mathrm{ab}}$ & $176.42^{\mathrm{ab}}$ & $129.06^{\mathrm{b}}$ & $138.63^{\mathrm{b}}$ & $135.18^{\mathrm{b}}$ & 52.77 & 0.01 \\
\hline $\operatorname{ALAT}(\mathrm{U} / \mathrm{I})$ & 42.70 & 43.45 & 42.00 & 40.83 & 40.30 & 39.35 & 38.91 & 20.04 & 1.00 \\
\hline Créatinine (mg/dl) & 1.33 & 1.15 & 1.12 & 1.21 & 1.35 & 1.36 & 1.47 & 0.64 & 0.95 \\
\hline Urea $(\mathrm{mg} / \mathrm{dl})$ & $0.66^{\mathrm{a}}$ & $0.60^{\mathrm{ab}}$ & $0.69^{\mathrm{a}}$ & $0.71^{\mathrm{a}}$ & $0.40^{\mathrm{b}}$ & $0.68^{\mathrm{a}}$ & $0.77^{\mathrm{a}}$ & 0.22 & 0.18 \\
\hline Total cholesterol (mg/dl) & 120.78 & 123.64 & 122.94 & 114.99 & 116.65 & 119.65 & 127.04 & 38.61 & 0.99 \\
\hline Triglycerides (mg/dl) & 71.95 & 77.31 & 70.01 & 80.89 & 77.25 & 83.05 & 85.28 & 36.68 & 0.97 \\
\hline LDL (mg/dl) & 55.09 & 55.03 & 54.29 & 42.88 & 49.93 & 54.14 & 47.49 & 23.66 & 0.99 \\
\hline HDL (mg/dl) & 106.04 & 107.51 & 100.63 & 106.86 & 110.13 & 109.43 & 114.18 & 64.22 & 1.00 \\
\hline
\end{tabular}

a,b: Means on the same row with different superscripts are significantly different $(\mathrm{P}<0.05) \cdot \mathrm{p}=$ probability. T0 $=$ negative control diet; $\mathrm{T} 0+=\mathrm{T} 0+0.1 \%$ of Doxycycline. 
Table 6. Intestinal microbial counts of broiler chickens fed on graded levels of Pentadiplandra brazzeana.

\begin{tabular}{ccccccccc}
\hline Bacterial load log10 UFC & T0 & T0 & $1 \mathbf{g} / \mathbf{L}$ & $\mathbf{2} \mathbf{g} / \mathbf{L}$ & $\mathbf{3} \mathbf{g} / \mathrm{L}$ & $\mathbf{4} \mathbf{g} / \mathbf{L}$ & $\mathbf{5} \mathbf{g} / \mathbf{L}$ & P-value \\
\hline Lactobacillus & $8.50 \pm 0.10^{\mathrm{b}}$ & $8.71 \pm 0.06^{\mathrm{a}}$ & $8.70 \pm 0.09^{\mathrm{a}}$ & $8.74 \pm 0.06^{\mathrm{a}}$ & $8.71 \pm 0.07^{\mathrm{a}}$ & $8.73 \pm 0.07^{\mathrm{a}}$ & $8.12 \pm 0.10^{\mathrm{c}}$ & 0.01 \\
Escherichia coli & $8.88 \pm 0.10^{\mathrm{a}}$ & $8.58 \pm 0.09^{\mathrm{b}}$ & $8.67 \pm 0.07^{\mathrm{b}}$ & $8.63 \pm 0.05^{\mathrm{b}}$ & $8.53 \pm 0.03^{\mathrm{b}}$ & $8.57 \pm 0.04^{\mathrm{b}}$ & $8.58 \pm 0.14^{\mathrm{b}}$ & 0.01 \\
Salmonella & $8.74 \pm 0.08^{\mathrm{a}}$ & $7.76 \pm 0.09^{\mathrm{d}}$ & $8.65 \pm 0.06^{\mathrm{ab}}$ & $8.59 \pm 0.06^{\mathrm{b}}$ & $8.59 \pm 0.03^{\mathrm{b}}$ & $8.54 \pm 0.08^{\mathrm{b}}$ & $8.11 \pm 0.11^{\mathrm{c}}$ & 0.01 \\
\hline
\end{tabular}

a,b,c, : Means on the same row with different superscripts are significantly different $(\mathrm{P}<0.05) . \mathrm{p}=$ probability. $\mathrm{T} 0=$ negative control diet; $\mathrm{T} 0+=\mathrm{T} 0+0.1 \%$ of Doxycycline.

the inclusion of 1, 2, 3 and $4 \mathrm{~g} P$. brazzeana powder per liter of water, but was comparable to antibiotic, while the reverse trend was observed with Escherichia coli count. Samonella counts significantly $(\mathrm{p}<0.05)$ decreased with $2,3,4$ and 5 g $P$. brazzeana in drinking water compared to the negative control ration. Bird fed on antibiotic medicated diet recorded the lowest $(\mathrm{p}<0.05)$ Samonella counts. Regarding the bacterial species, the inclusion of 2, 3 and $4 \mathrm{~g} P$. brazzeana powder in drinking water and antibiotic markedly $(\mathrm{p}<0.05)$ increased the number of lactic acid bacteria colonies as compared to salmonella and E. coli.

\section{Discussion}

The incorporation of graded levels of $P$. brazzeana powder in drinking water had no significant effect on feed intake (FI) with the exception of birds receiving $5 \mathrm{~g}$ of $P$. brazzeana/L who recoded the lowest FI of all the treatment. The decrease in FI observed with $5 \mathrm{~g}$ of $P$. brazzeana powder in this study could be attributed to the presence of alkaloids in this spice which have progressively induced a bitter taste of the water with increasing level of the spice powder and was not well appreciated by the animals, causing a decreased in water intake and consequently FI. The present result agrees with the findings of Kana et al. [6] who reported a significant decreased in feed intake with $4 \mathrm{~g}$ Dichostachys glomerata/kg of broiler feed. These authors explained the results by the high concentration of antinutritional, or strong odour of this spice that may have caused the feed to be unpalatable. As reported by Hernandez et al. [17], optimization of feed intake with feed additives from plant origin is controversial and depends on the quantity administrated.

Throughout the study period, live body weight and body weight gain of birds fed on 1, 2 and $3 \mathrm{~g}$ P. brazzeana/L of drinking water were significantly higher as compared to chickens fed on the negative control diet and comparable to birds fed antibiotic. This result was similar to the finding of Vivian et al. [18] who reported that aqueous extract of ginger markedly improved growth performance of broilers chickens. Similary, Al-Yasiry et al. [19] also reported that 2 and $3 \mathrm{~g} / \mathrm{l}$ of Boswellia carterii and Boswellia serrata improved body weight and weight gain of broiler chickens. The improvement of body weight with these spices in water could be attributed to the presence of phenolic compounds, terpenoides and alkaloids which are also present in our study spice. These actives compounds can decreased microbial competition in the host for nutrients by reduc- 
ing the pathogens bacteria. They act by forming complexes with bacteria proteins, causing the destruction of bacterial membranes, making unavailable certain substrates for the bacteria and inactivate bacterial enzymes [14]. This is in agreement with the report of Mcmullin [20] who observed that the growth promoting effects of most herbs and extracts of spices act by killing parasites that hinder digestibility and reduced growth performance of birds. Several studies reported that phytobiotics improved intestinal health, animals are less exposed to microbial toxins and other undesired microbial metabolites [21] [22]. The improvement of the body weight of birds fed on antibiotic could be explain by the ability to modulate the microbiota by reducing pathogen bacteria (Escherichia coli and Salmonella) leading to the development of benefic bacteria (lactic bacteria).

The inclusion of 1,2 and $3 \mathrm{~g} P$. brazzeana/L powder led to a significant improved in FCR as compared to the negative control diet. This improvement in feed conversion ratio indicate an efficient nutrient utilization by the birds, due to the decrease of pathogen bacteria leading to the reduction of competition for nutrient and a best absorption of this nutrient by the animal. This result is in agreement with the finding of Al-yasiry et al. [19] who recorded a significant decreased in FCR with the inclusion of 2 and $3 \mathrm{~g}$ of Boswellia serrata in broilers water. This result is in contradiction with the finding of Ogagaoghene et al. [23] who register no significant effect with the inclusion of grade level of Xylopia aethiopica in broilers water. The decrease in feed conversion ratio in this study suggested that, the digestibility of feed and the absorption of nutrients are better in broiler fed on 1, 2 and $3 \mathrm{~g} P$. brazzeana powder through drinking water.

Dressing percentage is a better index of total edible meat after the visceral organs, blood and feathers have been removed [24]. Based on the present study, broilers receiving $\lg$ P. brazzeana powder per liter of drinking water recorded a higher carcass yield compared to the negative control group. The improvement in carcass yield may be resulted in an increase digestibility of nutrients and a better feed utilization with the addition of $1 \mathrm{~g} P$. brazzeana powder in drinking water. Suggesting that at this dose the secondary metabolites are more efficient in the broiler chickens. These results are concordant with those of Kongmun et al. [25] who reported the ability of garlic to improved digestibility and carcass yield of broiler chickens.

The inclusion of graded levels of $P$. brazzeana powder in drinking water of broiler chickens induced a significant increase in lactic acid bacteria count as compared to the negative control diet. Salmonella and Escherichia coli bacteria counts significantly decreased with the inclusion of different levels of $P$. brazzeana powder in drinking water as compared to the negative control diet. Antimicrobial property of the spice is considered to arise from phenols [26], an hydrophobic compounds present in spices and plants that intrude into the bacterial cell membrane, disintegrate the membrane structure and caused leakage thus making microbes less virulent [2]. Castillo et al. [27] reported that the mixture of cinnamaldehyde, capsicum oleoresin and carvacrol enhances the growth of lac- 
tobacilli, and so increases the ratio of lactobacilli to enterobacteria. So herbs and spices do not possess only the antimicrobial activity, but also modulate the composition of microbial population by prebiotic activity. Therefore, plant extracts rich in phenolic and other bioactive compounds may serve as potential natural antimicrobial agents [28] [29]. Bird supplemented with $5 \mathrm{~g}$ of P. brazzeana powder in water recorded the lowest salmonella and lactobacillus count. Suggesting that at this dose, the concentration of active metabolites present in this spice has a negative effect on lactobacillus growth. This can explain the lowest body weight recorded with the highest doses of this spice $n$ water.

Blood parameters reflect the healthy state of an organism and any changes happening to it could be an indication of unbalance feeding or disease attack. This study revealed that graded levels of $P$. brazzeana powder in drinking water did not have any significant effect on blood parameters. This corroborates the finding of Onu [30] who recorded no significant effect on WBC, RBC, Hgb, $\mathrm{MCV}, \mathrm{MCH}$ and $\mathrm{MCHC}$ when $0.25 \%$ garlic, ginger and a combination of garlic-ginger were incorporated in finisher broiler's feed. Sajid et al. [31] reported that the supplementation of herbal medicine (Arsilvon super, Bedgen 40 and Hepa-cure) in drinking water did not significantly influence WBC, PCV and hemoglobin concentration of broiler chickens. The present results are in contradiction with the findings of Al-Kassie et al. [32], who recorded a significant decreased in WBC, RBC, Hgb and PCV when $0.25 \%, 0.5 \%, 0.75 \%$ and $1 \%$ hot red pepper was introduced in broiler's diet compared to the negative control diet. Furthermore, Vivian et al. [18] reported a significant increase in WBC, RBC and $\mathrm{Hgb}$ compared to the negative control treatment when $50 \mathrm{ml}$ ginger, garlic and a combination of the two were incorporated in broiler's drinking water. Fluctuations in red blood cell value of avian blood are normal phenomenon and may be associated with the physiological status of birds [33].

This study revealed that supplementing broiler chicken with graded level of $P$. brazzeana powder had no significant effect on serum content in ALAT and ASAT. This result suggests that active ingredients present in the spice didn't had harmful effect on the liver. This result corroborate the finding of Kana et al. [7] which revealed that, the incorporation of graded level of Dichrostachys glomerata in broiler diet did not significantly affect the serum contain in ALAT and ASAT. This observation contradicted the results of Rehman et al. [34] which revealed that given a mixture of aqueous extracts of medicinal plants to broiler induced a decrease in ASAT and ALAT. Serum urea level is an index which reflects the status of protein metabolism, renal function and nutrition of the body. The serum content in urea significantly decreased with $3 \mathrm{~g}$ Pentadiplandra brazzeana, thus showing that at this dose the spice improves protein synthesis in broilers, decreases protein decomposition speed and increases the efficiency of nitrogen use. While, serum content in creatinine was not significantly affected by graded level of the spice in drinking water. This result is close to those of Ebile et al. [35] which revealed that administrating graded level of Dichrostachys 
glomerata in quail feed had no significant effect on the serum content in creatinine and urea. Feeding broiler with graded level of this spice through drinking water did not markedly affected serum cholesterol profile. However, LDL-cholesterol serum level was lower in chicken fed on different level of the spice. This could be explained by the inhibiting effects of triterpenes present in the spice on HMG-CoA reductase, a key enzyme in cholesterol synthesis. This result is similar to the finding of Ebile et al. [35] which reported that feeding quail with graded level of Dichrostachys glomerata had no marked effect on total cholesterol, triglyceride, HDL and LDL-cholesterol.

\section{Conclusion}

This study revealed that, inclusion up to $3 \mathrm{~g}$ Pentadiplandra brazzeana powder in a litter of drinking water can be used as substitute for antibiotics for gut microbiota modulation and better growth of broiler chickens without any adverse effects on haemato-biochemical parameters.

\section{Conflicts of Interest}

The authors declare no conflicts of interest regarding the publication of this paper.

\section{References}

[1] Gakunga, J.N., Mirianga, B., Muwonge, H., Sembajwe, L.F. and Kateregga, J. (2013) Antidiarrheal Activity of Ethanolic Fruit Extract of Psidium guayava in Castor Oil Induced Diarrhea in Albino Rats. National Journal of Physiology and Pharmacology, 3, 191-197. https://doi.org/10.5455/njppp.2013.3.100620131

[2] Windisch, W.M., Schedle, K., Plitzner, C. and Kroismayr, A. (2008) Use of Phytogenic Products as Feed Additives for Swine and Poultry. Journal of Animal Science, 86, 140-148. https://doi.org/10.2527/jas.2007-0459

[3] Jang, I.S., Ko, Y.H., Kang, S.Y. and Lee, C.Y. (2007) Effect of a Commercial Essential Oil on Growth Performance, Digestive Enzyme Activity and Intestinal Microflora Population in Broiler Chickens. Animal Feed Science Technology, 134, 304-315. https://doi.org/10.1016/j.anifeedsci.2006.06.009

[4] Alloui, N., Ben Aksa, S. and Alloui, M.N. (2011) Utilization of Fenugreek (Trigonella Foenum-Graecum) as Growth Promoter for Broiler Chickens. Journal of World Poultry Research, 2, 25-27.

[5] Karangiya, V.K., Savsani, H.H., Patil, S.S., Garg, D.D., Murthy, K.S., Ribadiya, N.K. and Vekariya, S.J. (2016) Effect of Dietary Supplementation of Garlic, Ginger and Their Combination on Feed Intake, Growth Performance and Economics in Commercial Broilers. Veterinary World, 9, 245-250.

https://doi.org/10.14202/vetworld.2016.245-250

[6] Kana, J.R., Mube, K.H., Ngouana, T.R., Tsafong, F., Komguep, R., Yangoue, A. and Teguia, A. (2017) Effect of Dietary Mimosa Small Bell (Dichostachys glomerata) Fruit Supplement as Alternative to Antibiotic Growth Promoter for Broiler Chicken. Journal of World Poultry, 7, 27-34.

[7] Kana, J.R., Mube, K.H., Ngouana, T.R., Yangoue, A., Komguep, R., Tsafong, F. and Teguia, A. (2017) Growth Performance and Serum Biochemical Profile of Broiler 
Chickens Fed on Diets Supplemented with Afrostyrax lepidophyllus Fruit and Bark as Alternative to Antibiotic Growth Promoters. Journal of Veterinary Medicine and Research, 4, 1095.

[8] Kana, J.R., Mube, K.H., Ngouana, T.R., Komguep, R., Yangoue, A., Tsafong, F. and Teguia, A. (2017) Growth Performances and Serum Biochemical Response of Broiler Chickens Fed on Diet Supplemented with Tetrapleura tetrapleura Fruit Powder as Substitute to Antibiotic Growth Promoters. International Journal of Innovation and Applied Studies, 21, 68-76.

[9] Pentadiplandra Brazzeana Baill. https://www.prota4u.org/database/protav8.asp? $\mathrm{fr}=1 \& \mathrm{~kg}=\mathrm{pe} \& \mathrm{p}=$ Pentadiplandra+bra zzeana+Baill

[10] Newinger, H.D. (2000) African Traditional Medicine. A Dictionary of Plant Use and Applications. Medipharm, Scientific Publishers, Stuttgart.

[11] Cimanga, K.R., Lubiba, N.Z., Makila, B.M.F., Tona, L.G., Kambu, K.O., Vlietinck, A.J. and Pieters, L. (2018) Biological Activities of Arredoul Jaune, a Phytomedicine Based Ethanol Extract from Fresh Roots of Pentadiplandra brazzeana Baill. (Pentadiplandaceae) Used as an Antidiarrhoeal Drug in Kisangani-Democratic Republic of Congo. European Journal of Biomedical and Pharmaceutical Sciences, 5, 130-139.

[12] Ngbolua, K.N., Rafatro, H., Rakotoarimanana, H., Ratsimamanga, U.S., Mudogo, V., Mpiana, P.T. and Tshibangu, D.S.T. (2011) Pharmacological Screening of Some Traditionally-Used Antimalarial Plants from the Democratic Republic of Congo Compared to Its Ecological Taxonomic Equivalence in Madagascar. International Journal of Biological and Chemical Sciences, 5, 1797-1804. https://doi.org/10.4314/ijbcs.v5i5.3

[13] Kouitcheu, M.L.B, Kuiate, J.R. and Oyono, E.J.L (2011) Screening of Some Plant Used in the Cameroonian Folk Medicine for the Treatment of Infectious Diseases. International Journal of Biology, 3, 13-21. https://doi.org/10.5539/ijb.v3n4p13

[14] Abdou Bouba, A., Njintang, Y.N., Foyet, H., Scher, J., Montet, D. and Mbofung, C. (2012) Proximate Composition, Mineral and Vitamin Content of Some Wild Plants Used as Spices in Cameroon. Food and Nutrition Sciences, 3, 423-432. https://doi.org/10.4236/fns.2012.34061

[15] Kuete, V., Kruche, B., Youns, M., Voukeng, I., Fankam, A., Tankeo, S., Lacmata, S. and Efferth, T. (2011) Cytotoxicity of Some Cameroonian Spices and Selected Medicinal Plant Extracts. Journal of Etnopharmacology, 134, 803-812. https://doi.org/10.1016/j.jep.2011.01.035

[16] Steel, R.G.D. and Torrie, J.H. (1980) Principles and Procedures Statistic. A Biometrical Approach. 2nd Edition, McGraw Hill, New York.

[17] Hernandez, F., et al. (2004) Influence of Two Plant Extracts on Broilers Performance, Digestibility, and Digestive Organ Size. Poultry Science, 83, 169-174. https://doi.org/10.1093/ps/83.2.169

[18] Vivian, U.O., Harriet, M.N.F., Solomon, O.O. and Joesph, O.U. (2015) Evaluation of Growth Performance, Haematological and Serum Biochemical Response of Broiler Chickens to Aqueous Extract of Ginger and Garlic. Journal of Agricultural Science, 7, 167-173. https://doi.org/10.5539/jas.v7n4p167

[19] Al-Yasiry, R.M.A., Jawad, S.A.H., Menati, K.J., Naji, S.A. and Lokman, I.H. (2016) Effects of Boswellia carterii and Boswellia serrata in Drinking Water on the Growth Performance, Hematology Traits and Immune Response of Broiler Chicken. Journal of Food and Dairy Technology, 4, 27-37.

[20] Mcmullin, P. (2000) The Future of Anti-Microbial Growth Promoter Alternative for 
Poultry Production. In the New Millennium. International Poultry Production, 8, 1-30.

[21] Nuhu, A.M., Mshelis, M.S. and Yakubu, Y. (2000) Antimicrobial Screening of the Bark Extract of Pterocarpus erinaceus Tree. Journal of Chemical Society of Nigeria, 25, 85-86.

[22] Kambizi, L. and Afolayan, A.J. (2001) An Ethnobotanical Study of Plants Used for the Treatment of Sexually Transmitted Disease (Njovhera) in Guruve District, Zimbabwe. Journal of Ethnopharmacology, 77, 5-9. https://doi.org/10.1016/S0378-8741(01)00251-3

[23] Ogagaoghene, J.S., Ifeanyi, U., Bernard, I.O. and Theresa, O.K. (2014) Performance, Antimicrobial Effect and Carcass Parameters of Finisher Broilers Given Xylopia aethiopica Dried Fruits (Grains of Selim) as Additive. Agricultura Tropica et Subtropica, 47, 124-130. https://doi.org/10.2478/ats-2014-0017

[24] Ugwu, S.O.C. and Onyimonyi, A.E. (2008) Carcass, Organ and Organoleptic Characteristics of Spent Layers Fed Bambara Nut Sievates. International Journal of Poultry Science, 7, 81-84. https://doi.org/10.3923/ijps.2008.81.84

[25] Kongmun, P., Wanapat, M., Pakdee, P., Navanukraw, C. and Yu, Z. (2011) Manipulation of Rumen Fermentation and Ecology of Swamp Buffalo by Coconut Oil and Garlic Powder Supplementation. Livestock Science, 135, 84-92. https://doi.org/10.1016/j.livsci.2010.06.131

[26] Muanda, F., Kone, D., Dicko, A., Soulimani, R. and Younos, C. (2011) Phytochemical Composition and Antioxydant Capacity of Three Malian Medicinal Plant Parts. Evidence-Based Complementary and Alternative Medicine, 2011, Article ID: 674320. https://doi.org/10.1093/ecam/nep109

[27] Castillo, M. (2008) Do Probiotics Work in Turkeys? Poultry International, 47, 26-27.

[28] Luther, M., Parry, J., Moore, J., Meng, J., Zhang, Y., Cheng, Z. and Yu, L. (2007) Inhibitory Effect of Chardonnay and Black Raspberry Seed Extracts on Lipid Oxidation in Fish Oil and Their Radical Scavenging and Antimicrobial Properties. Food Chemistry, 104, 1065-1073. https://doi.org/10.1016/j.foodchem.2007.01.034

[29] Mohamed, E., Abd El-Hack, Samir, A., Mahgoub, M.A. and Kuldeep, D. (2015) Influences of Dietary Supplementation of Antimicrobial Cold Pressed Oils Mixture on Growth Performance and Intestinal Microflora of Growing Japanese Quails. International Journal of Pharmacology, 11, 689-696.

https://doi.org/10.3923/ijp.2015.689.696

[30] Onu, P.N. (2010) Evaluation of Two Herbal Spices as Feed Additives for Finisher Broilers. Biotechnology and Animal Husbandry, 26, 383-392. https://doi.org/10.2298/BAH1006383O

[31] Sadji, Q.H., ul Haq, A., Asghar, N., ur Rehman, S., Akhtar, P. and Abbas, G. (2015) Effect of Herbal Medicine Supplementations (Arsilvon Super, Bedgen40 and Hepa-Cure Herbal Medicines) on Growth Performance, Immunity and Haematological Profile in Broilers. Advances in Zoology and Botany, 3, 17-23.

[32] Al-kassie, G.A.M., Al-Nasrawi, M.A.M. and Ajeena, S.J. (2011) The Effect of Using Hot Red Pepper as a Diet Supplement on Some Performance Traits in Broilers. Pakistan Journal of Nutrition, 10, 842-845.

[33] Ogbe, A.O. and Affiku, J.P. (2011) Proximate Study, Mineral and Anti-Nutrient Composition of Moringa oleifera Leaves Harvested from Lafia, Nigeria: Potential Benefits in Poultry Nutrition and Health. Journal of Microbiology Biotechnology 
and Food Science, 1, 296-308.

[34] Rehman, S., Durrani, F.R., Chand, N., Khan, R.U. and Fawad, U.R. (2011) Comparative Efficacy of Different Schedules of Administration of Medicinal Plants Infusion on Hematology and Serum Biochemistry of Broiler Chicks. Research Opinions in Animal and Veterinary Sciences, 1, 8-14.

[35] Ebile, D.A., Kana, J.R., Edie, N.L., Pimagha, M.H., Nguefack, D.G., Ngouana, T.R., Mube, K.H. and Fonteh, A.F. (2018) Growth Performance, Gut Microbiota and Haemato-Biochemical Profile of Quails Fed Diet Supplemented with Graded Levels of D. glomerata Fruit Powder. Animal and Veterinary Sciences, 6, 80-87. https://doi.org/10.11648/j.avs.20180605.13 